\title{
Article
}

\section{Recycled PET Sand for Cementitious Mortar}

\author{
Angélica Faria Campanhão ${ }^{1}$, Markssuel Teixeira Marvila 1,2,*, Afonso R. G. de Azevedo 1,3 (D), \\ Tulane Rodrigues da Silva ${ }^{1}$, Roman Fediuk ${ }^{4, *}$ (D) and Nikolai Vatin ${ }^{5}$ D
}

1 LAMAV-Advanced Materials Laboratory, State University of the Northern Rio de Janeiro, Av. Alberto Lamego, 2000, Campos dos Goytacazes 28013-602, Brazil; angelicacampanhao@gmail.com (A.F.C.); afonso@uenf.br (A.R.G.d.A.); tuhrodrigues_@hotmail.com (T.R.d.S.)

2 CRP-Rio Paranaíba Campus, UFV-Federal University of Viçosa, Rodovia BR 230 KM 7, Rio Paranaiba 38810-000, Brazil

3 LECIV-Civil Engineering Laboratory, State University of the Northern Rio de Janeiro, Av. Alberto Lamego, 2000, Campos dos Goytacazes 28013-602, Brazil

4 Polytechnic Institute, Far Eastern Federal University, 690922 Vladivostok, Russia

5 Peter the Great St. Petersburg Polytechnic University, 195251 St. Petersburg, Russia; vatin@mail.ru

* Correspondence: markssuel.marvila@ufv.br (M.T.M.); roman44@yandex.ru (R.F.)

Citation: Campanhão, A.F.; Marvila, M.T.; de Azevedo, A.R.G.; da Silva,

T.R.; Fediuk, R.; Vatin, N. Recycled PET Sand for Cementitious Mortar. Materials 2022, 15, 273. https:// doi.org/10.3390/ma15010273

Academic Editor: Gabriele Milani

Received: 15 December 2021

Accepted: 25 December 2021

Published: 30 December 2021

Publisher's Note: MDPI stays neutral with regard to jurisdictional claims in published maps and institutional affiliations.

Copyright: (c) 2021 by the authors Licensee MDPI, Basel, Switzerland. This article is an open access article distributed under the terms and conditions of the Creative Commons Attribution (CC BY) license (https:// creativecommons.org/licenses/by/ $4.0 /)$.

\begin{abstract}
Cementitious materials cause a great impact on the environment due to the calcination of clinker and the extraction of non-renewable mineral resources. In this work, the replacement of quartz sand from the river by PET sand was evaluated at levels of $10 \%, 20 \%$, and $30 \%$. Tests were performed in the fresh state through consistency, air retention, density, and incorporated air and in the hardened state for compressive strength, flexural strength, density, capillarity, and water absorption. The results show that PET sand is viable in contents of up to $10 \%$, improving the mechanical properties of the mortar and without compromising its workability and incorporated air properties. Above that level, the loss of properties is very excessive, mainly of workability and incorporated air. The incorporated air of the $30 \%$ composition, for example, reaches $24 \%$, an excessive value that impacts the properties of the hardened state, making it impossible to use the material at levels greater than $20 \%$. It is concluded that the use of recycled PET sand is a possibility that contributes to sustainable development, as it reduces the extraction of quartz sand from the river, a non-renewable mineral resource.
\end{abstract}

Keywords: PET; recycling; mortars; Portland cement

\section{Introduction}

Mortars are construction materials used for different purposes in civil construction, such as laying blocks, covering ceilings and walls, or smoothing surfaces [1,2]. They are usually produced with binders, such as Portland cement and hydrated lime, fine aggregate, and water. The use of these materials is problematic from an environmental point of view, mainly due to the clinkerization needed to obtain Portland cement and the high extraction of mineral resources to produce the binders and to be used as fine aggregate [3-5].

Quartz sand from rivers or dunes is usually used as fine aggregate in concrete and mortar. However, the extraction of this material is highly harmful to the environment due to the lack of natural recovery of mineral resources, which are extracted at a much faster rate than they are formed [6,7]. This situation demands the attention of researchers from all over the world, who started to develop research aiming to use recycled residues as aggregates in cementitious materials.

Some relevant research that evaluated the use of recycled materials replacing natural sand are highlighted as follows: Azevedo et al. (2020) [8] evaluated the replacement of natural sand by construction and demolition waste at levels of $25 \%, 50 \%$, and $100 \%$. There was a gain in mechanical properties with the use of $R C D$, associated with the better packing provided by the residue. It is known that the material used as sand must be inert and must 
not interfere with the hydration of the cement and the reaction of other binders. However, as shown by [8,9], this material must present adequate particle size to reduce porosity, contributing to the packing and mechanical strength of cementitious materials. The results obtained by Azevedo et al. (2020) [8] were promising and justify the objective of the present research.

Gencel et al. (2021) [6] evaluated the replacement of natural sand by expanded vermiculite in geopolymeric mortars. The authors evaluated $15 \%$ and $30 \%$ replacement contents and found that, in addition to the reduction in density, which was already expected due to the nature of the expanded vermiculite, the mechanical strength results were equivalent to the reference composition produced with natural sand. In addition, there were positive results in the thermal conductivity tests, proving the feasibility of replacing natural sand. Other promising research has also evaluated the replacement of natural sand: Marvila et al. (2020) [10], who evaluated the replacement of natural sand by rock residue in gypsum mortars for restoration of historic structures and Amaral et al. (2020) [11], who evaluated the replacement of natural sand by rock residue in cement mortars for wall cladding and block laying, among other researches that verified the use of paper waste [12-14] and glass waste $[15,16]$ as sand in cementitious mortars.

In all these researches, the successful replacement of natural sand is only possible when the recycled material has an adequate granulometry, favoring packing, and when the material is inert. This feature is a great attraction for the use of PET waste since the material is inert in cementitious materials and favors packaging when properly used. This was tested in the research by Silva et al. (2021) [17], where the authors used PET waste to produce soil cement blocks. The results obtained by the authors prove that the material does not chemically interact with the cement but allows an increase in mechanical strength. This proves the reduction in porosity of this type of recycled aggregate.

In addition to its use in cementitious materials, it is observed that PET has applications when used to reinforce polymer composites. Mhanna et al. (2020) [18] evaluated how the thermal effect alters the mechanical properties of fiber-reinforced polymer (FRP) systems with PET through numerical modeling and experimental research. The authors concluded that FRPs produced with PET have a different behavior from traditional materials, where high levels of ductility of these materials are observed before failure in comparison with conventional FRPs. This is a positive feature that demonstrates the advantages of using PET in different types of materials.

In addition to the direct application of PET, other works highlight the application of polymeric systems reinforcing cementitious materials, such as the work by Hawileh et al. (2014) [19], where the authors evaluated the mechanical behavior of concrete beams reinforced with polymeric systems. The results obtained highlight that the use of polymeric systems increases the ductility of concrete beams, a beneficial factor since cementitious materials present problems regarding this property.

These results were confirmed in other later studies, such as the works by Hawileh et al. (2019) [20] and Naser et al. (2021) [21], where through experimental research, modeling using Finite element modeling, and through bibliographic consultation, the authors proved the use of polymeric materials (such as PET) together with cementitious materials. In addition, they proved the ductility gain that these materials provide when applied in conjunction with concrete and other cement-based materials.

Considering this information, it is noteworthy that the objective of this manuscript is to evaluate the influence of recycled PET sand as a substitute for natural sand at levels of $0-30 \%$ in cementitious mortars. The main properties in the fresh state were evaluated, such as consistency index, incorporated air, and water retention, and the main properties in the hardened state through tests of tensile strength in bending, compressive strength, density, and water absorption. 


\section{Materials and Methods}

The materials used in the research were ordinary Portland cement (OPC) composite, containing approximately $80 \%$ clinker and $20 \%$ blast furnace slag, and hydrated lime $(\mathrm{CH})$, containing at least $90 \%$ hydrated composite. In addition, natural sand from a quartz river, extracted in Campos dos Goytacazes, RJ, Brazil, was used. In addition, recycled PET sand extracted from an industry in the region was used, with the particle size adjusted for applications in cementitious materials.

Figure 1 shows the granulometry of the aggregates used. It is important to highlight that the granulometry of recycled PET sand was chosen to be equivalent to the granulometry of natural sand. This can be proven by the curvature coefficient of the aggregates, which was 3.0 for natural sand and 2.9 for recycled sand, and by the uniformity coefficient, calculated as 0.9 for natural aggregate and 1.1 for the recycled aggregate.

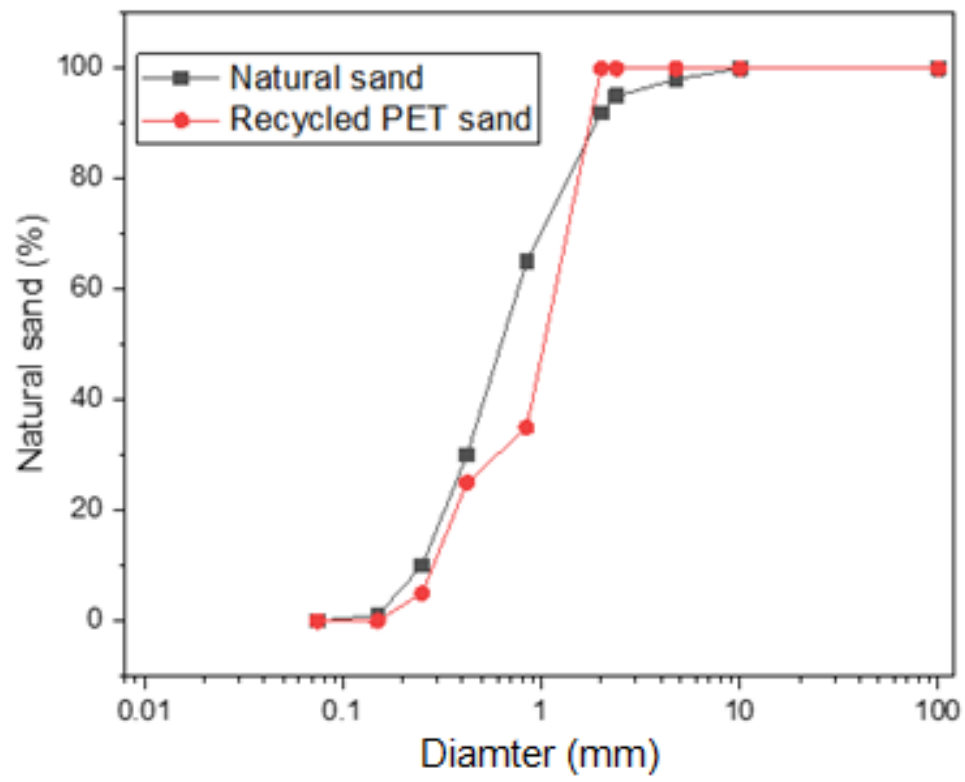

Figure 1. Granulometry of aggregates.

The composition of mortar used in the research was 1:1:6:1.4 (cement: hydrated lime: sand: water), chosen based on previous works that evaluated mortars for application in wall coverings and for settlement of blocks $[1,3,22,23]$. The replacement performed was in levels from 0 to $30 \%$, using the amounts defined in Table 1.

Table 1. Compositions studied in the research.

\begin{tabular}{cccccc}
\hline Composition & OPC (g) & CH (g) & $\begin{array}{c}\text { Natural } \\
\text { Sand }(\mathbf{g})\end{array}$ & $\begin{array}{c}\text { Recycled } \\
\text { PET Sand (g) }\end{array}$ & Water (g) \\
\hline $0 \%$ & 150 & 150 & 900 & 0 & 210 \\
$10 \%$ & 150 & 150 & 810 & 90 & 210 \\
$20 \%$ & 150 & 150 & 720 & 180 & 210 \\
$30 \%$ & 150 & 150 & 630 & 270 & 210 \\
\hline
\end{tabular}

The quantities established in Table 1 were mixed in a mortar, following the procedures of NBR 13276 [24] and EN-BS 4551 [25]. They were then used to assess the fresh-state tests. The tests carried out were the consistency test, which consists of measuring the horizontal spread of the mortar under controlled conditions, correlating this information with the workability of the material. Still in the fresh state, mass density and incorporated air tests were carried out by the pressureometric method, following NBR 13278 [26] and water retention by the modified Buchner funnel method, using the recommendations of NBR 13277 [27] and EN-BS 4551 [25]. 
Then, $40 \times 40 \times 160$-mm prismatic specimens were molded, always using 3 repetitions for each composition and in each test evaluated in the hardened state. The molding of the samples followed the procedure of NBR 13279 [28]. The curing procedure was carried out at an ambient temperature of $25^{\circ} \mathrm{C}$, for 28 days, according to NBR 13279 [28] and EN-BS 4551 [25]. This same standard sets the standards for flexural strength and compressive strength tests, carried out with the aid of an Instron universal test press with a 1000-kg capacity S charge bill. The speed used in the test was $50 \mathrm{~N} / \mathrm{s}$ in the flexural strength test and $500 \mathrm{~N} / \mathrm{s}$ in the compressive strength test.

Other tests were carried out in a complementary way in the hardened state: mass density test, through NBR 13280 [29] and water absorption test by immersion, using the procedures of NBR 9778 [30]. Finally, the capillary test was carried out to assess the capillary phenomena in the material, using the procedure of NBR 15259 [31] and EN-BS 4551 [25].

\section{Results and Discussion}

Figure 2 presents the consistency index results. It is observed that the composition of $0 \%$ and $10 \%$ present results compatible with the international bibliography, which recommends the use of a limit of 265 to $255 \mathrm{~mm}$ of scattering [23,32]. However, the $20 \%$ and $30 \%$ compositions showed a high loss of workability. This is related to the absorption of water promoted by recycled PET sand, which sequesters the free water available to improve spreading, and consequently increases the internal friction of the grains that make up the mortar, excessively impairing workability [33]. This characteristic even harms other properties of the material in the hardened state, such as mechanical resistance and water absorption, since the lack of workability prevents the molding of specimens from taking place efficiently.



Figure 2. Consistency Index Results.

Figure 3 shows the density results in the fresh state and incorporated air. A reduction in density in the fresh state is observed with the use of recycled PET sand. This can be explained by the density of the material, approximately $1.65 \mathrm{~g} / \mathrm{cm}^{3}$, while the density of natural sand is $2.65 \mathrm{~g} / \mathrm{cm}^{3}$. Density reduction is something positive as long as it does not affect the other properties studied [11,34]. The incorporated air content, on the other hand, has an adverse behavior. It is observed that compositions $0 \%, 10 \%$, and $20 \%$ do not have similar incorporated air, around 7.5\%. However, the 30\% composition has a very excessive incorporated air content, around $24 \%$. This is a big problem, as it causes porosity in the hardened cementitious matrix and reduces mechanical strength. It can be seen in the figure that there was a large increase in incorporated air, as the PET incorporation content increased from $20 \%$ to $30 \%$. This change cannot be attributed to the difference in density, since, as seen in Figure 3, there was not the same change in behavior in this property. Thus, 
the best explanation for the increase of air incorporated in the composition $30 \%$ is related to the lack of homogeneity of the material and the absorption of water from recycled PET sand, which forms a surface with low adhesion to cement in the areas surrounding the material, responsible by lifting the incorporated air [35].

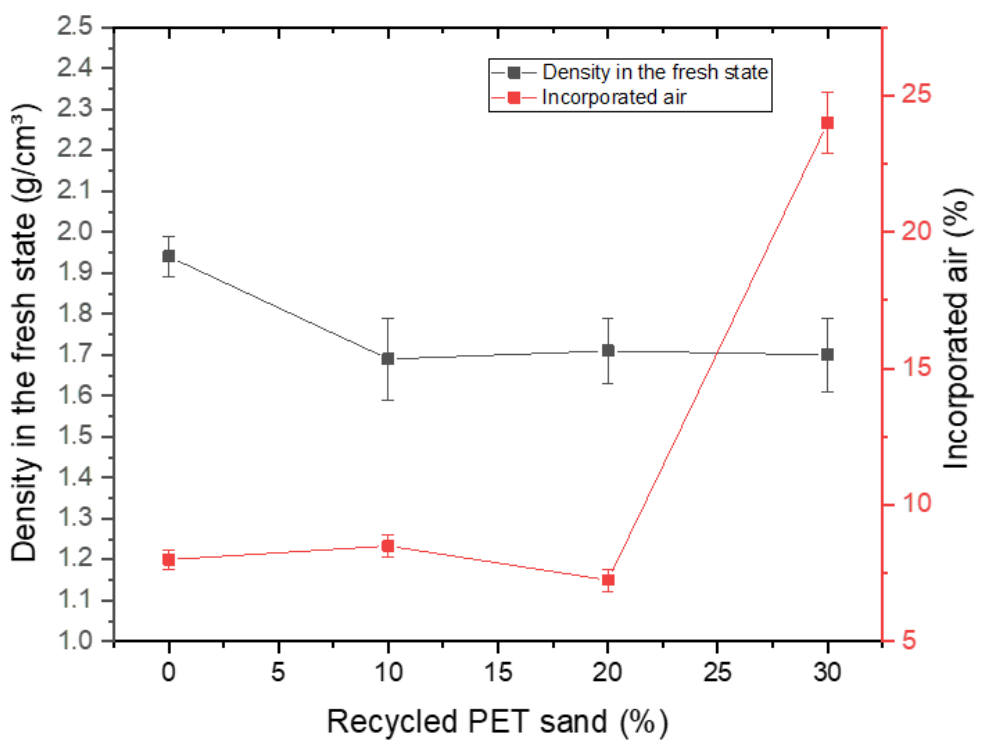

Figure 3. Density results in fresh state and incorporated air.

Figure 4 presents the water retention results. An increase in water retention is observed as the recycled PET sand content increases, which is directly related to the material's water absorption. The water retention of mortars must not present values below $75 \%$, as this can harm the mechanical resistance of the material developed through the hydration of the OPC [12]. However, the retention cannot be higher than $95 \%$ because in this case, there will be a deficiency in the adhesion between the mortar and the applied substrate [36]. This adhesion occurs through stress transfer bridges developed when the substrate can suck cement paste from the mortar. In this sense, the $20 \%$ and $30 \%$ mortars do not meet the requirements established by international references.

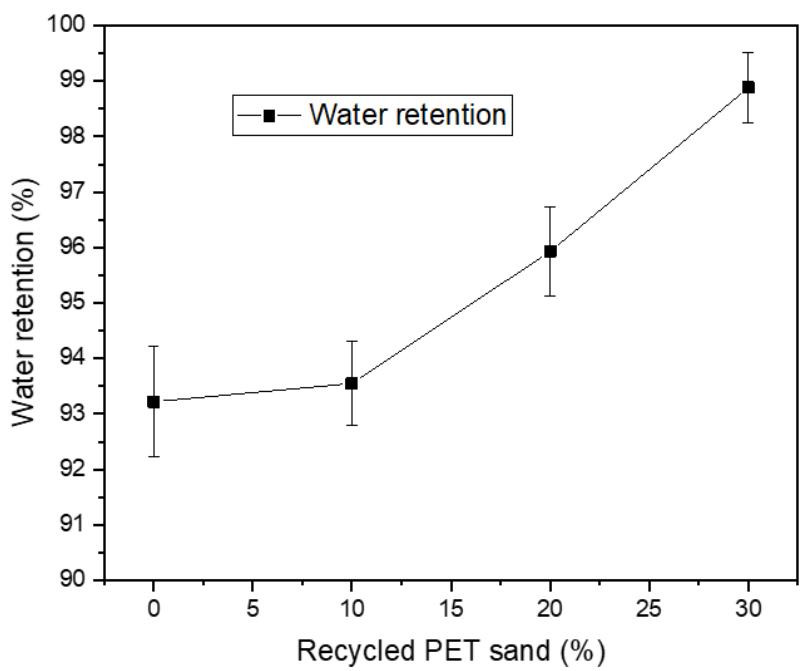

Figure 4. Water retention results.

Figure 5 presents the results of flexural strength of mortars, while Figure 6 presents the results of compressive strength. According to authors who study this type of material, the flexural strength of mortars varies between 1 and $4.5 \mathrm{MPa}$. Some authors even suggest that 
the mortar cannot present excessive strength values because this makes the material more rigid, compromising the performance of the material when it is in service [1]. Azevedo et al. (2020) [12] obtained values ranging from 0.8 MPa to 1.1 MPa replacing natural sand with sand from waste paper; Marvila et al. (2019) [3] obtained values from 1.0 MPa to 1.1 MPa with the same mortar composition. Similar results were obtained by Bonfim et al. (2021) [37] and Souza et al. (2020) [38]. Therefore, the flexural strength values are compatible. However, mortars with $20 \%$ and $30 \%$ recycled PET sand are less than $1 \mathrm{MPa}$ and are not compatible with the application. An interesting way to reduce the drop in strength would be the use of PET in its saturated form. This would reduce the water absorption caused by using PET in dry form and would likely have a positive impact on the mechanical properties, which would not have such a sharp drop, as seen in Figures 5 and 6 .

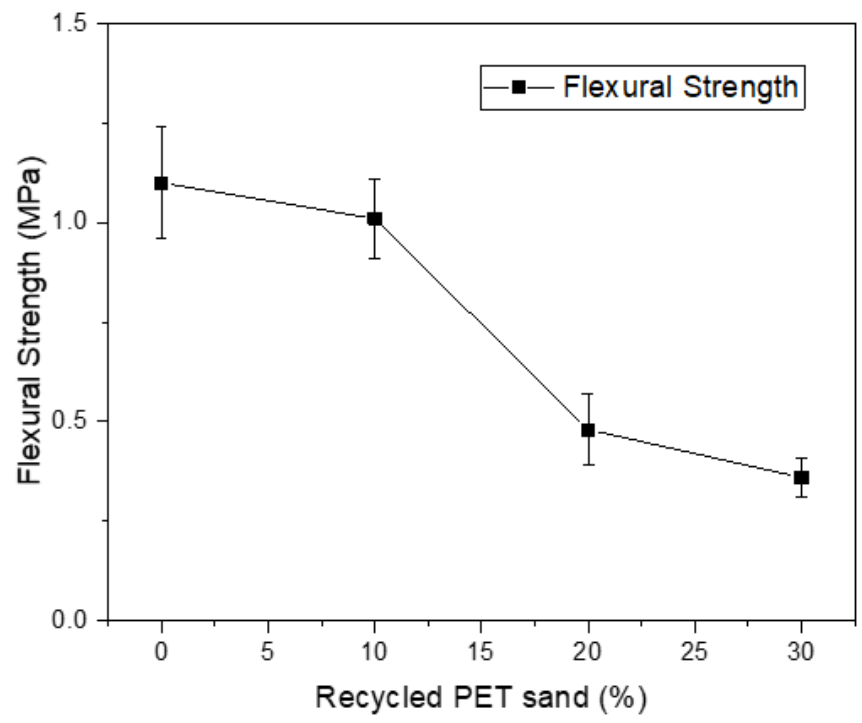

Figure 5. Flexural strength results.

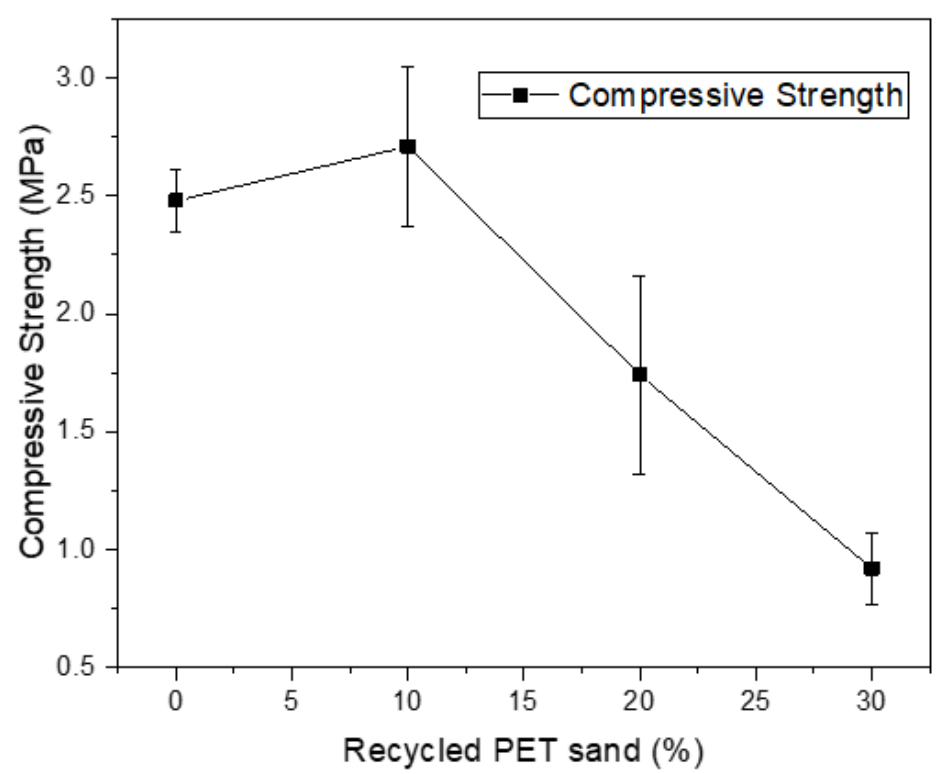

Figure 6. Compressive strength results.

Compressive strength, on the other hand, usually presents higher values since cementitious materials are very resistant to compression. Some results obtained by other authors 
are highlighted as follows: Azevedo et al. (2020) [8] obtained values of approximately 2.63 $\mathrm{MPa}$, while Azevedo et al.'s (2020) [12] values were around 2.6 MPa. The results obtained for the $0 \%$ and $10 \%$ compositions are compatible, but the values for the $20 \%$ and $30 \%$ compositions are very low and are not possible for the proposed application. It is observed that the $30 \%$ composition showed a very sharp drop in strength. This is directly related to the high content of air incorporated in the material, which influenced the porosity of the material and consequently provided the reduction of mechanical properties.

Figure 7 shows the mass density results in the hardened state. Again, a reduction in density is observed as larger amounts of recycled PET sand are used. This feature is beneficial if no other factors are harmed. The values obtained are compatible with other similar studies, such as by Bonfim et al. (2021) [37] and Souza et al. (2020) [38].

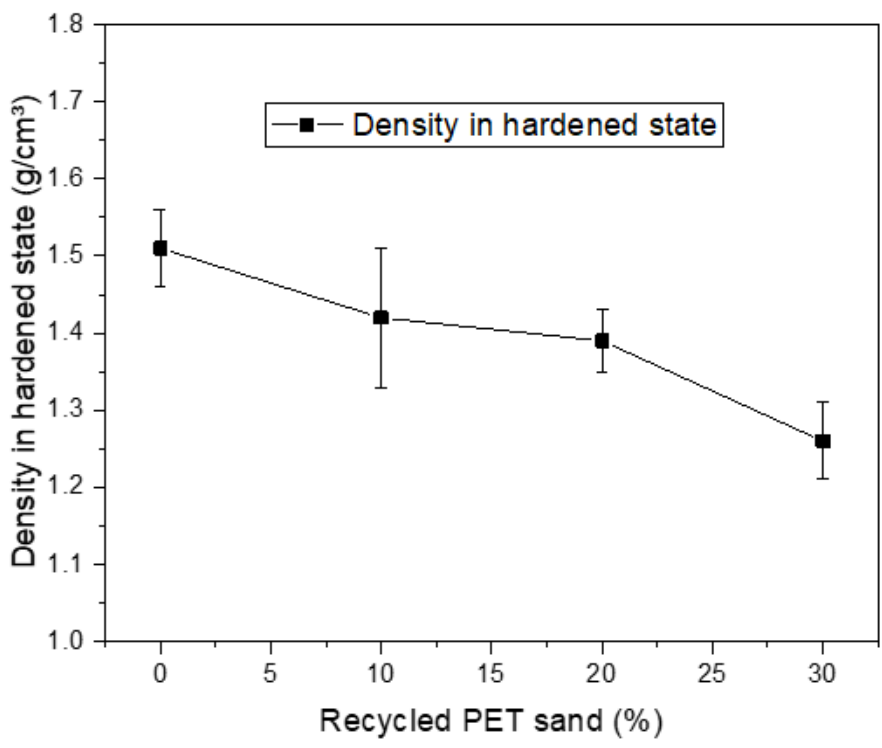

Figure 7. Density results in the hardened state.

Figure 8 presents the results of water absorption and capillarity. It is observed that water absorption increases with increasing PET recycled sand content. The mortars containing $20 \%$ and $30 \%$ of PET again present excessive values, above $14 \%$. Comparing the results of other researches, it is observed that Souza et al. (2020) [38] obtained values between 15 and 16.8\%, while Marvila et al. (2020) [39] obtained values between 12 and 14\%. Thus, it is observed that the values obtained for water absorption are compatible although the $20 \%$ and $30 \%$ compositions have presented excessive values. This may be associated with an increase in the porosity of the material and, consequently, a decrease in mechanical strength, observed in Figures 5 and 6.

The capillary results are related to the phenomenon of capillary water absorption and are problematic in mortars. It is observed that $0 \%, 10 \%$, and $20 \%$ had capillarity coefficient below $20 \mathrm{~g} / \mathrm{dm}^{2} \cdot \mathrm{min}^{1 / 2}$; however, the 30\% composition again presented excessive and non-standard values. Comparing with the results of other researches, it is observed that Azevedo et al. (2020) [8] resented a capillary coefficient between 15 and $18 \mathrm{~g} / \mathrm{dm}^{2} \cdot \mathrm{min}^{1 / 2}$; Bonfim et al. (2021) [37] obtained values around $20 \mathrm{~g} / \mathrm{dm}^{2} \cdot \mathrm{min}^{1 / 2}$; and Azevedo et al. (2020) [12] presented values ranging between 14 and $18 \mathrm{~g} / \mathrm{dm}^{2} \cdot \mathrm{min}^{1 / 2}$. Therefore, the results obtained are consistent. 


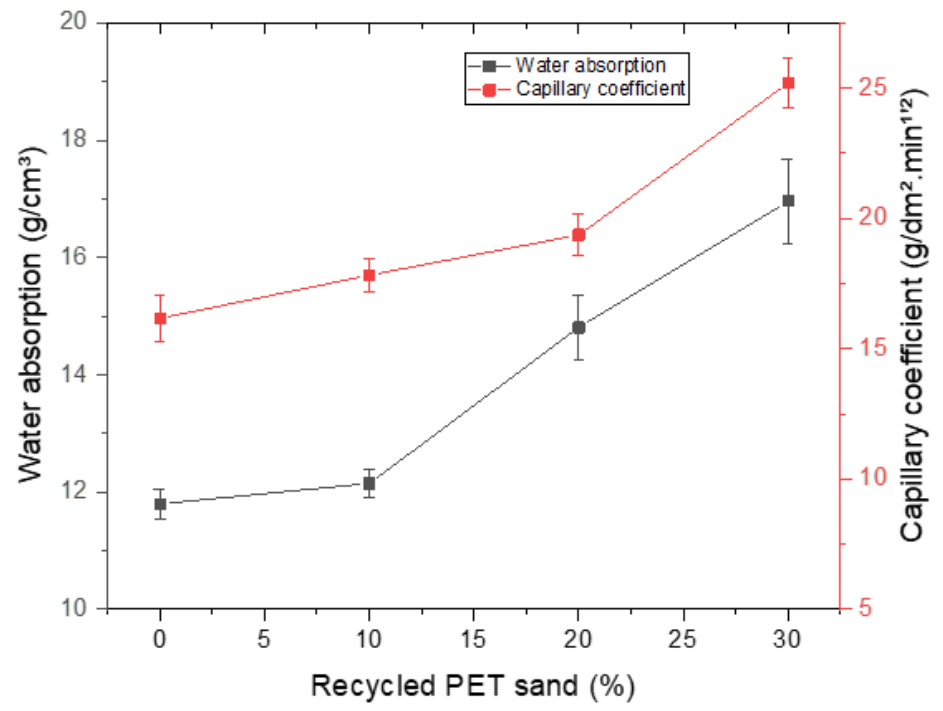

Figure 8. Water absorption and capillary results.

\section{Conclusions}

Based on the results obtained, it is possible to conclude that:

- The use of recycled PET sand in contents of $20 \%$ and $30 \%$ promotes a drop in the consistency index and a drop in workability due to the water absorption of the PET. These compositions, especially the one with $30 \%$, presented an excess of incorporated air and low values of flexural and compressive strength when compared to other mortars and other similar researches. In addition, the use of $20 \%$ and $30 \%$ contents promoted an increase in porosity, as observed in the results of water absorption and capillarity.

- The composition with $10 \%$ recycled PET sand did not harm the properties of the mortar, presenting values very close and equivalent to the reference composition containing only natural sand. These results prove the viability of using recycled PET sand at $10 \%$ levels in cement mortars.

Author Contributions: Conceptualization, M.T.M., A.R.G.d.A., and N.V.; methodology, A.F.C. and T.R.d.S.; validation, A.R.G.d.A. and R.F.; formal analysis, M.T.M.; investigation, A.F.C. and T.R.d.S.; resources, N.V.; data curation, M.T.M., A.R.G.d.A., and N.V.; writing-original draft preparation, M.T.M.; writing-review and editing, A.R.G.d.A. and R.F.; project administration, M.T.M. and A.R.G.d.A.; funding acquisition, A.R.G.d.A. All authors have read and agreed to the published version of the manuscript.

Funding: The research is partially funded by the Ministry of Science and Higher Education of the Russian Federation under the strategic academic leadership program 'Priority 2030' (Agreement 075-15-2021-1333 dated 30 September 2021).

Institutional Review Board Statement: Not applicable.

Informed Consent Statement: Not applicable.

Data Availability Statement: Not applicable.

Acknowledgments: 1 . The authors thank FAPERJ for its support and funding. 2. The study was carried out using the equipment of interregional multispeciality and interdisciplinary center for the collective usage of promising and competitive technologies in the areas of development and application in industry/ mechanical engineering of domestic achievements in the field of nanotechnology (Vladimir State University).

Conflicts of Interest: The authors declare no conflict of interest. 


\section{References}

1. Marvila, M.T.; Alexandre, J.; de Azevedo, A.R.G.; Zanelato, E.B. Evaluation of the use of marble waste in hydrated lime cement mortar based. J. Mater. Cycles Waste Manag. 2019, 21, 1250-1261. [CrossRef]

2. Fediuk, R.S.; Lesovik, V.S.; Mochalov, A.V.; Otsokov, K.A.; Lashina, I.V.; Timokhin, R.A. Composite binders for concrete of protective structures. Mag. Civ. Eng. 2018, 6, 208-218. [CrossRef]

3. Marvila, M.T.; Alexandre, J.; Azevedo, A.R.G.; Zanelato, E.B.; Xavier, G.C.; Monteiro, S.N. Study on the replacement of the hydrated lime by kaolinitic clay in mortars. Adv. Appl. Ceram. 2019, 118, 373-380. [CrossRef]

4. Loganina, V.; Frolov, M.; Fediuk, R. Developed heat-insulating dry mortar mixes for the finishing of aerated concrete walls. Mag. Concr. Res. 2021, 73, 890-903. [CrossRef]

5. Amran, M.; Fediuk, R.; Vatin, N.; Lee, Y.H.; Murali, G.; Ozbakkaloglu, T.; Klyuev, S.; Alabduljabber, H. Fibre-reinforced foamed concretes: A review. Materials 2020, 13, 4323. [CrossRef]

6. Gencel, O.; Gholampour, A.; Tokay, H.; Ozbakkaloglu, T. Replacement of Natural Sand with Expanded Vermiculite in Fly Ash-Based Geopolymer Mortars. Appl. Sci. 2021, 11, 1917. [CrossRef]

7. Fediuk, R.S. Mechanical Activation of Construction Binder Materials by Various Mills. In IOP Conference Series: Materials Science and Engineering; IOP Publishing: Bristol, UK, 2016. [CrossRef]

8. Azevedo, A.R.G.; Cecchin, D.; Carmo, D.F.; Silva, F.C.; Campos, C.M.O.; Shtrucka, T.G.; Marvila, M.T.; Monteiro, S.N. Analysis of the compactness and properties of the hardened state of mortars with recycling of construction and demolition waste (CDW). $J$. Mater. Res. Technol. 2020, 9, 5942-5952. [CrossRef]

9. Lesovik, V.S.; Zagorodnyuk, L.K.; Babaev, Z.K.; Dzhumaniyazov, Z.B. Analysis of the Causes of Brickwork Efflorescence in the Aral Sea Region. Glas. Ceram. (Engl. Transl. Steklo I Keram.) 2020, 77, 277-279. [CrossRef]

10. Marvila, M.T.; Azevedo, A.R.G.; Barroso, L.S.; Barbosa, M.Z.; de Brito, J. Gypsum plaster using rock waste: A proposal to repair the renderings of historical buildings in Brazil. Constr. Build. Mater. 2020, 250, 118786. [CrossRef]

11. Amaral, L.F.; Girondi Delaqua, G.C.; Nicolite, M.; Marvila, M.T.; de Azevedo, A.R.G.; Alexandre, J.; Fontes Vieira, C.M.; Monteiro, S.N. Eco-friendly mortars with addition of ornamental stone waste-A mathematical model approach for granulometric optimization. J. Clean. Prod. 2020, 248, 119283. [CrossRef]

12. de Azevedo, A.R.G.; Alexandre, J.; Marvila, M.T.; de Castro Xavier, G.; Monteiro, S.N.; Pedroti, L.G. Technological and environmental comparative of the processing of primary sludge waste from paper industry for mortar. J. Clean. Prod. 2019, 249, 119336. [CrossRef]

13. Chernysheva, N.; Lesovik, V.; Fediuk, R.; Vatin, N. Improvement of Performances of the Gypsum-Cement Fiber Reinforced Composite (GCFRC). Materials 2020, 13, 3847. [CrossRef] [PubMed]

14. Elistratkin, M.Y.; Lesovik, V.S.; Zagorodnjuk, L.H.; Pospelova, E.A.; Shatalova, S.V. New point of view on materials development. In IOP Conference Series: Materials Science and Engineering; IOP Publishing: Bristol, UK, 2018.

15. de Azevedo, A.R.G.; Alexandre, J.; Zanelato, E.B.; Marvila, M.T. Influence of incorporation of glass waste on the rheological properties of adhesive mortar. Constr. Build. Mater. 2017, 148, 359-368. [CrossRef]

16. Tolstoy, A.D.; Lesovik, V.S.; Glagolev, E.S.; Krymova, A.I. Synergetics of hardening construction systems. In IOP Conference Series: Materials Science and Engineering; IOP Publishing: Bristol, UK, 2018.

17. da Silva, T.R.; Cecchin, D.; de Azevedo, A.R.G.; Valadão, I.; Alexandre, J.; da Silva, F.C.; Marvila, M.T.; Gunasekaran, M.; Garcia Filho, F.; Monteiro, S.N. Technological Characterization of PET—Polyethylene Terephthalate-Added Soil-Cement Bricks. Materials 2021, 14, 5035. [CrossRef] [PubMed]

18. Mhanna, H.H.; Hawileh, R.A.; Abuzaid, W.; Naser, M.Z.; Abdalla, J.A. Experimental Investigation and Modeling of the Thermal Effect on the Mechanical Properties of Polyethylene-Terephthalate FRP Laminates. J. Mater. Civ. Eng. 2020, 32, 04020296. [CrossRef]

19. Hawileh, R.A.; Rasheed, H.A.; Abdalla, J.A.; Al-Tamimi, A.K. Behavior of reinforced concrete beams strengthened with externally bonded hybrid fiber reinforced polymer systems. Mater. Des. 2014, 53, 972-982. [CrossRef]

20. Hawileh, R.A.; Musto, H.A.; Abdalla, J.A.; Naser, M.Z. Finite element modeling of reinforced concrete beams externally strengthened in flexure with side-bonded FRP laminates. Compos. Part B Eng. 2019, 173, 106952. [CrossRef]

21. Naser, M.Z.; Hawileh, R.A.; Abdalla, J. Modeling Strategies of Finite Element Simulation of Reinforced Concrete Beams Strengthened with FRP: A Review. J. Compos. Sci. 2021, 5, 19. [CrossRef]

22. de Azevedo, A.R.G.; Marvila, M.T.; da Silva Barroso, L.; Zanelato, E.B.; Alexandre, J.; de Castro Xavier, G.; Monteiro, S.N. Effect of granite residue incorporation on the behavior of mortars. Materials 2019, 12, 1449. [CrossRef]

23. Zanelato, E.B.; Alexandre, J.; de Azevedo, A.R.G.; Marvila, M.T. Evaluation of roughcast on the adhesion mechanisms of mortars on ceramic substrates. Mater. Struct. Constr. 2019, 52, 53. [CrossRef]

24. NBR 13276. Argamassa Para Assentamento e Revestimento de Paredes e Tetos—Determinação do Índice de Consistência. Associação Brasileira de Normas Técnicas: São Paulo, Brazil, 2016.

25. British Standard BS 4551. Mortar. Methods of Test for Mortar and Screed-Chemical Analysis and Physical Testing. The British Standards Institution: London, UK, 2005.

26. ABNT NBR 13278. Argamassa Para Assentamento e Revestimento de Paredes e Tetos—Determinação da Densidade de Massa e do Teor de ar Incorporado. Associação Brasileira de Normas Técnicas: São Paulo, Brazil, 2005. 
27. ABNT ABNT NBR 13277. Argamassa Para Assentamento e Revestimento de Paredes e Tetos—Determinação da Retenção de Água. Associação Brasileira de Normas Técnicas: São Paulo, Brazil, 2005.

28. ABNT NBR 13279. Argamassa Para Assentamento e Revestimento de Paredes e Tetos—Determinação da Resistência à Tração na Flexão e à Compressão. Associação Brasileira de Normas Técnicas: São Paulo, Brazil, 2005.

29. ABNT ABNT NBR 13280. Argamassa Para Assentamento e Revestimento de Paredes e Tetos—Determinação da Densidade de Massa Aparente no Estado Endurecido. Associação Brasileira de Normas Técnicas: São Paulo, Brazil, 2005.

30. ABNT NBR 9778. Argamassa e Concreto Endurecidos—Determinação da Absorção de Água, Índice de Vazios e Massa Específica. Associação Brasileira de Normas Técnicas: São Paulo, Brazil, 2011.

31. ABNT NBR 15259. Argamassa Para Assentamento e Revestimento de Paredes e Tetos—Determinação da Absorção de Água por Capilaridade e do Coeficiente de Capilaridade. Associação Brasileira de Normas Técnicas: São Paulo, Brazil, 2005.

32. Marvila, M.T.; Azevedo, A.R.G.; Alexandre, J.; Colorado, H.; Pereira Antunes, M.L.; Vieira, C.M.F. Circular economy in cementitious ceramics: Replacement of hydrated lime with a stoichiometric balanced combination of clay and marble waste. Int. J. Appl. Ceram. Technol. 2020, 18, 192-202. [CrossRef]

33. Zhang, P.; Zheng, Y.; Wang, K.; Zhang, J. A review on properties of fresh and hardened geopolymer mortar. Compos. Part B Eng. 2018, 152, 79-95. [CrossRef]

34. Marvila, M.T.; de Azevedo, A.R.G.; de Matos, P.R.; Monteiro, S.N.; Vieira, C.M.F. Rheological and the Fresh State Properties of Alkali-Activated Mortars by Blast Furnace Slag. Materials 2021, 14, 2069. [CrossRef] [PubMed]

35. Srinivas, M.K.; Alengaram, U.J.; Ibrahim, S.; Phang, S.M.; Vello, V.; Jun, H.K.; Alnahhal, A.M. Evaluation of crack healing potential of cement mortar incorporated with blue-green microalgae. J. Build. Eng. 2021, 44, 102958. [CrossRef]

36. Marvila, M.T.; Azevedo, A.R.G.; Alexandre, J.; Zanelato, E.B.; Azeredo, N.G.; Simonassi, N.T.; Monteiro, S.N. Correlation between the properties of structural clay blocks obtained by destructive tests and ultrasonic pulse tests. J. Build. Eng. 2019, $26,1556$. [CrossRef]

37. Bonfim, W.B.; de Paula, H.M. Characterization of different biomass ashes as supplementary cementitious material to produce coating mortar. J. Clean. Prod. 2021, 291, 125869. [CrossRef]

38. Tolentino Souza, A.; de Almeida Carvalhais, C.; dos Santos, W.J. Analysis of chemical admixtures combination on coating mortar using Simplex network method. Constr. Build. Mater. 2020, 239, 117796. [CrossRef]

39. Marvila, M.T.; Azevedo, A.R.G.; Monteiro, S.N. Verification of the application potential of the mathematical models of lyse, abrams and molinari in mortars based on cement and lime. J. Mater. Res. Technol. 2020, 9, 7327-7334. [CrossRef] 